\title{
ECONOMIC CONDITIONS OF THE DEVELOPMENT OF ELECTROMOBILITY IN POLAND AT THE BACKGROUND OF SELECTED COUNTRIES
}

\section{WOJCIECH DROŻDŻ, ${ }^{1}$ PRZEMYSŁAW STARZYŃSKI ${ }^{2}$}

\author{
1 University of Szczecin, Faculty of Management and Economics of Services, POLAND \\ e-mail:wojciech.drozdz@wzieu.pl \\ ${ }^{2}$ ENEA Operator Ltd., POLAND \\ e-mail: przemyslaw.starzynski@enea.pl
}

RECEIVED
ACCEPTED
JEL
CLASSIFICATION

KEYWORDS

ABSTRACT
10 December 2018

28 December 2018

L91, L94

electromobility, electric car

The text addresses the issue of the development of electromobility in the context of barriers and economic benefits. The first part presents legal regulations in the area of electromobility, which were implemented in Poland. The National framework for alternative fuels infrastructure policy, the act on electromobility and alternative fuels and the act on biocomponents and liquid biofuels have been defined and characterized. The next part identifies the most important economic changes that minimize the barriers to the implementation of electromobility. There are also examples of economic solutions for electric car owners in the USA, China, Great Britain, Switzerland, Norway and Sweden.

\section{Introduction}

Periodically in the media are presented different theories about the resources of the raw material that is oil. The development of technology and the increase in demand for raw material creates one of theories that states that oil is enough for less than $30-40$ years. According to information published by British Petroleum, if new deposits are not discovered and oil consumption remains at its present level, it will end around 2050 (BP Energy Outlook, 
2017). The Rystad Energy company presented data in 2017, which shows that the extraction of oil barrels is the lowest in 70 years and amounts to about 7 billion (Rystad 1, 2017). An alternative to the ending oil reserves may be an electric motor, which at the end of the second half of the nineteenth century was applicable not only on land, but also on water, under water and in the air.

Electromobility is an area that has become very common in recent years, and thus topics related to it are often mentioned in various media. Increased ecological awareness combined with technological progress and increase in oil prices led to a rebirth after almost half a century of forgetting the design of an electric car. For the revival of the idea of an electric car in the 21st century can be considered the introduction to the market in 2008 of the Tesla Roadster car, which was the first EV produced on a mass scale, equipped with lithium-ion battery. From then on, the number of electric vehicles is increasing. According to the International Energy Agency report, the number of fully electric, hydrogen and hybrid plug-in vehicles in the world reached in 2017 the level of 3.1 million copies, which is an increase of $57 \%$ from the previous years (IEA, 2017). At that time, more than 1 million electric cars were sold globally - 580 thousand in China (IEA, 2017), an increase of $54 \%$ compared to 2016 . The second place was taken by the United States, in which 280 thousand pieces were sold. France dominates in Europe, with nearly 120 thousand units sold (Statista, 2018). In the coming years, the expansion of electromobility will include Poland. This is thanks to the introduction of the governmental Strategy for Responsible Development adopted by the Council of Ministers on 14 February 2017, as well as detailed plans for the development of electric transport, which includes guidelines for determining the pace of changes in Europe and the world. The International Energy Agency estimates that the number of new electric cars will grow. By 2020, there will be around 20 million units, up to 60 million by 2025, and by 150 million by 2030 (IEA, 2017).

\section{Law regulations in the area of electromobility}

The Polish government considered electromobility as a key area, which is an indispensable element to ensure Poland's sustainable development based on innovation. The most important Polish strategic documents, that directly refer to the concept of electromobility includes the so-called Clean Transport Package, which consists of:

1. Electromobility Development Plan in Poland (Development plan, 2017).

2. National framework for alternative fuels infrastructure policy (National framework..., 2017).

3. Act amending the act on biocomponents and liquid biofuels (Act on biocomponents, 2018).

The Electromobility Development Plan in Poland is the basic document defining the scope of development in this area for the coming years. The main scope of this act is the development of electromobility for society, industry and stability of the power network, which is an important factor due to the change of load resulting from connecting electric cars to chargers. The last element, which is an important element of energy security, focused on the attention of Polish Transmission System Operator S.A. and thus it was used to develop an analysis of changes in the demand for electricity. The purpose of this analysis was to estimate the impact of electric cars on the energy peak demand by 2030 and to develop potential preventive steps.

There are three main development stages according to the Polish Development Plan which differ in the maturity of the market and the necessary level of state involvement. The first preparatory phase will last until the end of 2018 and includes all work on appropriate legal regulations for public transport, conducting research projects, launching the first pilot projects, creating prototypes of Polish electric cars and targeting public financing in this fields. In the second phase, estimated for 2019-2020, it is planned to create business models for the 
dissemination of infrastructure and vehicles, construction of infrastructure in selected agglomerations and along the TEN-T network, commercialization of research projects launched in the preparatory phase, transition of Polish producers from the prototype phase to the production and support for the purchase of electric vehicles. The last path of the program includes a five-year period during which the electromobility market in Poland is expected to stabilize by gradually withdrawing instruments to support the purchase of electric vehicles, creating strong industrial entities working for the Polish electric cars, widespread use of electric vehicles by public administration, completion of electricity network preparation for cooperation with electric vehicles and entry into the landscape of Polish cities of electric transport.

The second document from the Package for Clean Transport is the National Framework for Alternative Fuels Infrastructure Policy. The document concerns the infrastructure for all alternative fuels being a substitute for crude oil. The most important guidelines of the adopted document include the definition of targets for the number of charging points for electricity. The document predicts that by 2020 , there will be 50 thousand electric vehicles in Polish cities. Whereas the aim by 2025 is 1 million electric cars moving on polish roads (National framework..., 2017).

The third document is the Act on biocomponents and liquid biofuels (the Act on biocomponents, 2018), in which the creation of the Low-Emission Transport Fund is an important element. The essence of the Act is supporting the development of infrastructure for alternative fuels, producers of low-emission vehicles, low-emission public transport and co-financing of parking fees for EV.

The Electromobility Development Plan in Poland together with the national policy framework for the development of alternative fuels infrastructure was the basis for the work on the Act on Electromobility and Alternative Fuels (Act on electromobility, 2018), which, after approval, came into life on 22nd February 2018. The development of the Act by the Ministry of Energy aimed to implement Directive No. 2014/94/EU of the European Parliament and of the Council of 22nd October, 2014 on the development of alternative fuels infrastructure, defining conditions and rules for the deployment of alternative fuels infrastructure in transport and rules for the provision of services charging electric vehicles and refueling vehicles powered by natural gas. In addition, the Act defines the obligations of public entities in the area of development of alternative fuels infrastructure and related obligations to public all required information. The Directive obliges Member States to build a charging infrastructure for electric vehicles by 31st December, 2020. This should ensure free movement of electric cars in urban and densely populated areas. In the created model, the government focus on the creation of an appropriate legal framework aimed at necessary development for charging infrastructure for electric, hybrid and natural gas or hydrogen-powered vehicles, which has been developed without appropriate regulations so far. The legislator introduces regulations to create specific infrastructure of charging points. According to the current law, about 6 thousand stations will be created in Poland by the end of 2020 for electric vehicles up to $22 \mathrm{~kW}$, as well as 4 hundred with a power exceeding $22 \mathrm{~kW}$. They will be deployed in 32 urban agglomerations and densely populated areas. If such a minimum infrastructure is not created by then, the obligation to build a certain infrastructure will rest on the distribution system operators. The act provides for the possibility of separating by self-government the clean zone transport. This will allow the local authorities to designate a zone to which only vehicles powered by electricity, hydrogen and special fueled with natural gas will have free entry. In addition, the legislator assumes a system of incentives, among others exemption from parking fees, abolition of excise duty on electric cars, increase in amortization write-offs for companies, or the possibility of moving electric cars on bus lanes. The Act on electromobility and alternative fuels also imposes 
an obligation on local governments to develop ecological transport by providing a $50 \%$ share of electric vehicles in the state fleet. Obligation to design and build public utility buildings and multi-family residential buildings in a way that allows the parking spaces to be equipped with recharging points, or eliminating the obligation to obtain building permits for stations and vehicle charging points, are subsequent regulations included in the Act. The entry into force of individual provisions of the Act has been spread over time and will take place in stages up to 2028. The legislator also provides transitional periods to adapt current activities to new regulations. Another important document for the development of electromobility in Poland is the Strategy for Responsible Development (Development Strategy, 1999). In the area of electromobility, the priority is to increase transport accessibility and improve services related to the transport of goods and passengers, while reducing the negative impact on the environment using electric vehicles. The strategy assumes $16 \%$ share of alternative fuel buses, including electricity, in the total number of buses used for urban transport in 2030.

\section{Barpiers and economic benefits in implementing the principles of electromobility in Poland compared to selected countries}

Electromobility, which today is a new branch of industry and economy for Poland, can become one of the key elements of development. One should strive to create inseparable forms of business cooperation between the public and private sectors. Electromobility is inseparable from the area of new technologies, therefore it is necessary to move in the area of innovation and research and development activities. This approach requires the involvement of many entities and institutions operating in the area of new technologies, products and services.

The most important element that should be considered as one of the first goals to achieve is an adequate level of market saturation with electric vehicles (1 million cars estimated), especially in metropolitan areas. This number of cars will generate an additional demand for energy at the level of 4.3 TWh per year, which will contribute to an increase in revenues by 20 billion PLN from the sale of electricity, assuming that the average life of an electric vehicle will be about 10 years. The additional demand for electricity can be satisfied not only by the construction of new generation sources, but also by more efficient use of existing capacities. Proper investments are required to achieve expansion of network. The implementation of electric cars on the market will also contribute to the development of medium and low voltage networks and will also compensate for the so-called night valley or a drop in energy demand in the night(thanks to charging electric cars during the night). The increase of electric cars will significantly reduce the demand for oil consumption, which will increase energy independence. Compensate night valley bring better balancing the system and facilitating its integration with renewable energy sources. There will also be an opportunity to popularize innovative solutions, such as energy storage or intelligent management of energy sources. Today, it is difficult to say what challenges the energy sector will have to face, because there are no exact calculations indicating what investments should be made for the needs of the development of electromobility. According to the assumptions of the Ministry of Energy, by 2020 there should be up to 400 charging points. The ambitious targets for the development of electromobility in Poland will also require investments in the area of smart grids and smart metering. They will require access to significant capacities. The ambitious targets for the development of electromobility in Poland will also require investments in the area of smart grids and smart metering. This is due to the need for energy management when charging electric vehicles, which will be an unstable energy receiver. This is related to the model of behavior of electric vehicle users, who in most cases will load vehicles at the same time. With the assumption of the legislator (million electric cars) connecting such a number of vehicles even using low-power 
loaders, on the order of 4-5 kW, may increase the demand for power in the amount of 4-5 GW. Today, it accounts for about $10 \%$ of the installed capacity in the Polish power system (Cicha rewolucja..., 2016). The energy sector is already pursuing the ambitious goal set by the European Union, which talks about replacing at least $80 \%$ of meters for smart meters by 2020 (Directive, 2009). The development of the electromobility area can significantly accelerate the implementation of smart meters by facilitating the acquisition of financing for this purpose.

In recent years, the battery production market has become a rapidly growing area that gives distribution network operators the opportunity to create a demand management tool and apply new system services. Thanks to intelligent charging of electric vehicles, it will be possible to control the time of their access to the network depending on the period of demand or the power deficit in the energy system. It will allow smoothing the daily profile of energy demand and thus facilitating the management of the power units. The use of an intelligent power system will create a new area of services and new markets. Information from intelligent measuring systems will be received, processed and made available in real time, which will enable dynamic control of power consumption or dynamic management of energy prices. The market will create innovative companies in the field of ICT, information and communication technology and the demand for smart grid programming and smart metering services will increase. The applicable standards are insufficient and should be extended to include the integration of an electric vehicle with smart grid systems, smart metering, a home energy management system to ensure interoperability principles, communication interfaces as well as data models.

An important obstacle to the implementation on the mass scale of electric vehicles in Poland is their relatively high cost of purchase and operation, which results mainly from the high cost of batteries. Observing the battery production market, the forecasts are promising because the battery costs are getting smaller. An additional element causing a fall in prices of an electric vehicle will be its popularization, as well as emphasizing economic benefits that will result from the use of an electric vehicle in the form of achieving savings in relation to fuel costs. Publicly presented reports and studies of scientific units indicate that the cost of purchasing an electric vehicle is $60 \%$ higher than that of a conventional internal combustion engine (Media EFL, 2018). The significant cost of building fast-charging infrastructure combined with a high purchase cost and lack of incentive creates at the current stage of development of electromobility in Poland a certain dissonance. The Act on electromobility and alternative fuels focuses on the development of infrastructure and the legislator has scarcely devoted his place to the development of the electric vehicle market. Without a proper system of incentives allowances for electric vehicle users, Poland will not gain a competitive advantage from other economies. Nowdays, the only incentive is (for an ordinary user) the exemption from excise duty, while on the other hand for companies it is possible to recognize depreciation of earning an increased amount of 30 thousand EUR. An important role in reducing the economic barrier will have public institutions, which through the mechanisms of financial support in the interim period, will be able to stimulate demand for electric vehicles. When the electric cars start to compete on price with combustion cars, such support will be withdrawn. The system of incentives that have already been implemented in Europe and have been successful in the implementation of electromobility should be analyzed. This is important enough because Poland is a country characterized by high import of used cars powered by internal combustion engines. The incentive created should include, for example, subsidies for the purchase of an electric car while scrapping the combustion vehicle.

Analyzing current financial instruments implemented in Europe for electric car users, the most commonly used instruments to lower the purchase price are:

- a discount on the sale price, 
- exemption from sales tax or registration fees,

- VAT exemption,

- discounts in other taxes,

- exemption from parking fees, toll sections of roads or tunnels.

The government in China, as part of the central program, encourages the purchase of new electric vehicles, thanks to which the buyer can get a discount up to 8 thousand USD. In addition, residents of selected cities can obtain an additional discount of 9 thousand USD, which is paid from local government funds. A similar solution was used in Beijing and Shanghai, where the drop was to 6 thousand and USD 4,500 respectively (Electric vehicles, 2017). In France a situation where the buyer scrapes a diesel car in addition to a basic amount of EUR 6 thousand he receives an additional payment of 3,700 thousand EUR. Purchasers of an electric car living in the Paris agglomeration who scrapped an old car can obtain additional purchase support amounting to $25 \%$ of the value of electric vehicles (including cars, motorbikes, scooters or electric bikes). Entrepreneurs purchasing business electric vehicles receive tax breaks for purchase and for installation devices for charging electric vehicles (Electric vehicles..., 2017). In the USA, the owners of electric cars are entitled to federal tax relief of up to USD 7,500 as well as direct state subsidies of up to USD 2,500. Since 2011, the British government has been subsidizing the purchase of cars that emit less than 75 grams of $\mathrm{CO} 2$ per kilometer. The government supports the purchase of up to 4,500 pounds. The owners of electric van receive up to 8 thousand pounds. In Sweden, however, the surcharge is not an element of the vehicle price or other factors and amounts to approximately USD 4,400. (E-mobility..., 2017). A separate approach has been applied by Norway and Switzerland, which do not spend budgetary resources on support. The exemption of buyers of electric cars from certain taxes was applied, which in fact gives a similar result, because in both cases the price difference between comparable models of electric and combustion cars is significantly reduced. This approach is effective when there is an adequate level of taxation on the purchase of an internal combustion car.

Owners of electric cars in Denmark are exempt from the so-called green tax, and other taxes covering cars, and by the end of 2015 were also exempt from the registration fee. However, since the beginning of 2016, even electric cars have been subject to the basic registration fee rate, which will be increased every year until 2020, when all new vehicles will be covered by the same fees amounting to $105 \%$ of the car's value up to 79 thousand DKK (including VAT, or about 45 thousand PLN) and 180\% from the rest of the car's value (Denmark, 2015). The lowest tax breaks are obtained by buyers of electric cars in Switzerland, where they are exempt only from the import tax, which is $4 \%$ of the value. Decisions on additional incentives for the buyer are made in individual cantons and.

Transport policy tools are also important. They refer to a non-financial incentives, although some of their elements have a financial dimension, e.g. exemption from parking fees or exemption from charges, so-called congestion charging zones. The most important non-financial incentives include:

- the possibility of moving in a low-emission zone or zones with banned vehicles with internal combustion engines,

- exemption from periodic traffic bans,

- the possibility of driving bus passes,

- access to free parking lots,

- exemption from entry fees to congestion charging zones. 
It is important to ensure high functionality of electric cars when making longer journeys, which today in Poland is a significant obstacle to the development of electromobility. That is why the most popular support instruments in this field, both at the central and regional level, include:

a) subsidizing the purchase of a charging point for an electric car for private purposes;

b) development of public charging stations for electric cars, including points for quick charging near highways;

c) lowering the tariff for electricity for households with an electric car or reducing charging charges at public points.

In the area of electromobility, it is important to integrate organizational solutions in the metropolitan areas with the development of passenger car charging infrastructure and at the same time for the needs of public transport. "The main goal in the field of electromobility is to create a sustainable, open and effective mobility system for goods and people. Implementation of multimodal public transport, supporting alternative means of transport (apart from cars) and increasing the accessibility of public transport for the residents are the three main axes that will reduce congestion, pollution and increased efficiency of transport connections" (Drożdż, 2018, p. 128). Appropriate organizational activities, combined with introduced incentives to purchase private, company and public vehicles, will aim at creating expectations for the creation of the market, which will translate into multiplication of works in the field of infrastructure construction and the development of the electromobility industry in Poland.

\section{Conclusions}

Presentation of economic barriers and benefits of the development of electromobility is an attempt to signal the complexity of the presented issues, which concerns a new direction of development of the energy, automotive and IT market. Presented assumptions and thoughts along with the implementation of the assumptions of the Act will probably be verified by the market and users of electric vehicles in the near future. This will allow for further theses and assumptions regarding the evaluation of the electromobility development plan in metropolitan areas and thus the impact on economic factors of the implementation of electromobility in Poland. The development of electromobility is a continuation of the trend of electrification of the world economy and transport. The Electromobility Development Plan in Poland approved by the Polish government is not a new solution compared to other European countries. The specific goal of 1 million electric cars in 2025 is close to the one that Germany adopted in 2010 (BMVI, 2009). Similar assumptions were also adopted in 2014 in California (Leginfo, 2014). In recent years, electromobility strategies in the Netherlands, Sweden, Norway and other European countries have become comparable to the Polish strategy.

A significant impact on the development of electromobility in Poland is the cooperation of state authorities with the local authorities of individual regions and cities. It is also necessary to support public authorities in the creation of charging points infrastructure, implementation of tax concessions and subsidies.

In Poland, unlike many European countries, facilitations for electric vehicle owners are at the stage of creation and initiated at the level of local governments, eg exemption from fees in areas of parking. The high cost of buying an electric car and a small number of points for charging causes that people interested in new technologies or have high ecological awareness decide for the purchase. A visible problem in the subject of electromobility development is the social aspect in which one should bear in mind limited confidence in the implementation of innovative technologies related to the use of electric vehicles as well as infrastructure for charging electric vehicles. The correct approach to the issue of corporate social responsibility (CSR) will be important here, which in relation to sustainable 
development is to maintain the balance point between actions aimed at ensuring the achievement of objectives in the ecological, social and economic aspects.

\section{References}

Act on biocomponents (2018). Act of June 6, 2018 amending the Act on biocomponents and liquid biofuels and certain other acts. OJ 2018 item 1356. Retrieved from: http://prawo.sejm.gov.pl/isap.nsf/download.xsp/WDU20180001356/T/D20181356L.pdf.

Act on electromobility (2018). Act of 11 January 2018 on electromobility and alternative fuels. OJ 2018 item 317.Retrieved from: http:// prawo.sejm.gov.pl/isap.nsf/download.xsp/WDU20180000317/T/D20180317L.pdf.

BMVI (2009). German Federal Government's National Electromobility Development Plan. Retrieved from: https://www.bmvi.de/ blaetterkatalog/catalogs/219118/pdf/complete.pdf.

BP Energy Outlook (2017). Raport British Petroleum 2017. Retrieved from: https://www.bp.com/content/dam/bp/pdf/energy-economics/ energy-outlook-2017/bp-energy-outlook-2017.pdf (10.09.2018).

Cicha rewolucja w energetyce. Elektromobilność w Polsce (2016). Polityka Insight. Retrieved from: https://www.politykainsight. pl/_resource/multimedium/20106685.

Denmark (2015). Carregistration fees in Denmark. Retrieved from: https://denmark.trade.gov.pl/pl/dania/analizy-rynkowe/147250,oplatyrejestracyjne-samochodow-w-danii.html.pdf.

Development plan (2017). Electromobility Development Plan. Retrieved from: http://bip.me.gov.pl/node/26453.

Development strategy (1999). Poland's sustainable development strategy until 2025. Retrieved from: http://snep.edu.pl/sms/materialy/ strategia\%20zrownowazonego\%20rozwoju\%20polski\%20do\%20roku\%202025.pdf.

Directive (2009). Directive of European Parliament and Council 2009/72 / ec of 13 July 2009 concerning common rules for the internal market in electricity and repealing Directive 2003/54/EC. Retrieved from: http://kigeit.org.pl/FTP/PRCIP/Literatura/064_WE_ Dyrektywa_2009_72.pdf.

Drożdż, W. (2018). Idea Smart City. In: W. Drożdż (ed.), Elektromobilność w rozwoju miast (pp. 117-140). Warszawa: Wyd. Naukowe PWN.

Electric vehicle capitals of the world. Demonstrating the path to electric vehicle (2017). ICCT. Retrieved from: https://www.theicct.org/ sites/default/files/publications/Global-EV-Capitals_White-Paper_06032017_vF.pdf.

E-moblity: visions and development scenarios (2017). Retrieved from: https://www.efcongress.com/sites/default/files/e-mobilnosc.pdf.

IEA (2017). Global EV Outlook 2017 Two million and counting. Retrieved from: https://www.iea.org/publications/freepublications/ publication/GlobalEVOutlook2017.pdf.

Leginfo (2014). Vehicle retirement and replacement: Charge Ahead California Initiative. Retrieved from: http:/lleginfo.legislature.ca.gov/ faces/billNavClient.xhtml?bill_id=201320140SB1275\&search_keywords.

Media EFL (2018). Retrieved from https://media.efl.pl/releases/390745.

National framework for alternative fuels infrastructure development policy (2017). Retrieved from: http://bip.me.gov.pl/node/26450.

Rystad 1 (2017). All-time low for discovered resources in 2017: around 7 billion barrels of oil equivalent was discovered. Retrieved from: https://www.rystadenergy.com/newsevents/news/press-releases/all-time-low-discovered-resources-2017.

Statista (2018). Electric Car Sales Are Surging In China. Retrieved from: https://www.statista.com/chart/14098/electric-car-salesare-surging-in-china.

Cite this article aS: Drożdż, W., Starzyński, P. (2018). Economic conditions of the development of electromobility in Poland at the background of selected countries. European Journal of Service Management, 4 (28/2), 133-140. DOI: 10.18276/ejsm.2018.28/2-16. 